\title{
CORN-BREEDING WORK IN PUERTO RICO
}

\section{J. Vélez Fortuño}

\section{INTRODUCTION}

The improvement of corn in Puerto Rico by common breeding methods may produce results of remarkable importance to its agriculture. The great value of corn as food for human beings, as well as livestock, is well demonstrated by the fact that imports of corn and corn products amounted to 955,405 cwt. in the fiscal year $1949-50$, with a total value of $\$ 3,674,006$ (1). ${ }^{2}$ During 1947-48, the Island's total production amounted to only 184,000 cwt. with a total value of $\$ 887,000$.

The average production per acre is extremely low, 5 or 6 cwt. of shelled corn per "cuerda" ( 0.97 acre). Because of these poor yields, cultivation on a commercial scale is very limited, thus making the Island dependent on importations. High production costs also keep farmers from devoting large areas to corn.

The use of hybrid seed corn in the United States has increased the yields of corn per acre by at least 20 perent. The development of hybrid corn in Puerto Rico is necessary in order to increase actual yields. That is why the corn-breeding program carried on by the Station has as its objectives the isolation of desirable inbreds from which high-yielding hybrids may be produced, and the development of practical methods of dealing with them.

\section{Previous Work}

Although corn was grown in the Island even before the Spanish conquest, no organized effort has been made until recently to improve the crop.

Early efforts to improve our native varieties of corn by selection and hybridization were made at the Puerto Rico Experiment Station at Mayagüez by Thomas Bregger and W. P. Snyder, in 1921, and were continued by R. L. Davis, in $1924(2,3,4,5)$. Ear-to-row selection and pure-line breeding. were used for the improvement of native varrieties $(6,7,8,9,10,11)$.

As a result of these tests undertaken with the cooperation of the Isabela Substation a local variety from Isabela was found superior to the hybrids being tested. This variety, when crossed with the best $S_{5}$ line, and when

${ }^{1}$ Assistant Plant Breeder, Agricultural Experiment Station, University of Puerto Rico, Río Piedras, P. R. The author wishes to express his recognition to Messers. P. ronzález Ríos, F. Mariota Trías, and Efraín Boneta Gareía for their work during the time they were in eharge of this project and to Messers. A. Riollano, A. Rodríguez Cabrera, Luis B. Ortiz, C. M. Cabrera, L. Meyer, and R. Abrams for their assistance in the conduction of the yield tests.

${ }^{2}$ Numbers in parentheses refer to "Literature eited", p. 16. 
submitted to mass selection, produced the variety known as Mayorbela, which for the time being is our standard variety $(12,13)$.

During 1936-37, Roque (14) started a project on the improvement of native field corn at the Agricultural Experiment Station of the University of Puerto Rico at Río Piedras. Within this breeding program a number of inbred lines were developed and tested in top crosses and single crosses. $(15,16,17,18)$.

Lebedeff, $(19,20)$ selected 7 inbred lines and combined them into synthetic varieties. These synthetics did not outyield the Mayorbela variety, though they were found superior to the Diente de Caballo, which is the standard variety for the southwest area of the Island. $(21,22)$

The testing of synthetics was discontinued later on because of their inconsistent and unsatisfactory performance when compared with variety Mayorbela.

\section{Present Breming Program}

The primary objective of the corn-breeding program is the production of high-yielding hybrids by developing, selecting, and crossing pure lines. Over 500 selections from native and foreign stocks are actually in the process of inbreeding. A number of inbreds selected on the basis of their topcross performance are being tested in all possible single-cross combinations for evaluation of their specific combining ability. Based on these trials it is expected that the best double-cross combinations can be predicted, and final tests will be conducted before recommendations are made, based on their performance.

A complementary phase of this work consists in introducing and testing germ plasm from foreign countries. Strains of desirable genetic diversity may thus be isolated and utilized for hybridization, in appropriate combinations with native strains. The performance of the various foreign strains is also being studied with reference to their geographical sources.

Meanwhile immediate measures for the improvement of our commercial -varieties are being applied. S. C. Harland (24) proposed a new method for the improvement of open-pollinated varieties of corn. This method is rather economical and results may be obtained in a shorter time than with the pure-line method. It is under test now to determine its effectiveness for the improvement of native varieties of corn.

\section{Experimental and Breming Methods}

\section{SELECTION, COLLECTION, AND PRELIMINARY ISVALUATION OF MATERIAL FOR INBREEDING}

The first step for corn improvement was the collection of open-pollinated ears from different corn-growing areas of the Island. This procedure insures 
a reasonably accurate sampling of the different sources of native-yield genotypes which might be isolated and tested to be further utilized in the production of hybrid corn. Four hundred and sixty-three ear selections were collected in 30 "barrios" of 17 municipalities, for use as the foundation germ plasm for the development of inbred lines. (See table 1.)

Germ plasm from several foreign countries was introduced to be utilized for hybridization, in appropriate combinations with desirable native strains, if worth while. Actually 517 varieties or strains from the United States and 19 foreign countries are being tested and evaluated for their potential breeding value.

\section{DEVELOPMENT OF INBREED LINES}

Corn-breeding work consists of 3 main phases, namely: 1 . Developing inbred lines through inbreeding and selection for at least four consecutive generations; 2. testing and evaluating these lines, and; 3. determining the best combinations between these lines for the production of the highest yielding hybrids.

Seed samples from ears selected as foundation stock for the production of inbred lines were planted in 20 -ft. rows, 10 hills to each row. The best plants, judged by their vigor, freedom from insects, disease damage, etc., were self-pollinated by modern corn-breeding techniques. The ears obtained from the best plants were again selected for husk cover, size and shape of ear, kernel characters, insect and disease injury, etc. .

The selected ears were planted again. The same procedure used for selecting and selfing the ears in the field, and the selection made in the ear stage after harvest, were carried out continuously until the lines were fixed or became almost homozygous.

The inbreeding process screened out numerous defective or undesirable conditions such as various types of sterility, tassel seed, virescence, dwarf, etc. which appeared mostly in the second and third self-generations.

A variation in the number of self-pollinations was required by different lines to attain uniformity; this fluctuated between 4 and 7 selfings. At this stage the pure lines were ready to be tested for general combining ability.

TESTING INBRED LINES

The combining ability of inbred lines is evaluated by determining their yield potential in test crosses. An inbred line, a single cross, or an openpollinated variety may be used as tester for the production of these test crosses. No inbreds or hybrids were available as testers, so our standard variety Mayorbela was used for this purpose.

A selection of 100 practically homozygous native lines was top-crossed with the standard native variety Mayorbela, in 1949. A detasseled plot was 
TABLE 1.-Ear corn selections for pedigree-breeding collected in various corn-growing areas of Puerto Rico

\begin{tabular}{l|r|l|l}
\hline \multicolumn{1}{c}{ Pedigree No. } & $\begin{array}{c}\text { Number } \\
\text { of selec- } \\
\text { tions }\end{array}$ & "Barrio" & Municipality \\
\hline & North Section & \\
\hline $697-699$ & 3 & Cupey & Río Piedras \\
$814-817$ & 4 & Sabana Llana & do. \\
889 & 1 & & do. \\
$804-813$ & 10 & Carraizo & Trujillo Alto \\
$624-629$ & 6 & Buena Vista & Bayamón \\
$600-615 ; 700-713 ; 675-685$ & 41 & Cibuco & Corozal \\
$616-623 ; 659-668$ & 18 & Palmarejo & do. \\
$788-793$ & 6 & Palo Blanco & do. \\
$630-641 ; 726-731$ & 18 & Loma & Naranjito \\
$739-745$ & 7 & Cedro Abajo & do. \\
\hline & Interior & \\
\hline $794-801$ & 8 & Valenciano Abajo & Juncos \\
$802-803$ & 2 & Lirios & do. \\
$779-787$ & 9 & & Cidra \\
$746-757$ & 12 & & Cayey \\
$714-725 ; 758-766$ & 21 & La Plata & Aibonito \\
$642-658$ & 17 & Honduras & Barranquitas \\
$767-771$ & 5 & Quebrada Grande & do. \\
$772-778$ & 7 & Palo Hincado & do. \\
$669-674$ & 6 & Damián Arriba & Orocovis \\
$686-696 ; 732-738$ & 18 & Orocovis & do. \\
\hline
\end{tabular}

Southern and Southwestern Section

\begin{tabular}{l|r|l|c}
\hline $825-871$ & 47 & Pasto & Coamo \\
$872-882$ & 11 & Llano & do. \\
$975-985 ; 998 ; 1003-1014 ; 1092-1107$ & 40 & Llanos Costa & Cabo Rojo \\
do. \\
$959-967$ & 10 & Boquerón & Sabana Grande \\
$890-891$ & 9 & Machuchal & Lajas \\
$968-974 ; 986-992 ; 1015-1026 ; 1120$ & 27 & Parguera & do. \\
$1035-1042$ & 8 & Lajas Alato & do. \\
$1121-1134$ & 14 & Costa & do. \\
$1108-1119 ; 1027-1034$ & 20 & Piedras Blancas & Guayanilla \\
$1043-1054$ & 12 & Quebrada & do. \\
$1055-1078$ & 24 & Magas & do. \\
$1079-1091$ & 13 & Jagua & do. \\
\hline
\end{tabular}

Eastern Section

\begin{tabular}{l|l|l|}
\hline $818-824$ & 7 & Vieques \\
\hline
\end{tabular}


JOURNAL OF AGRICULTURE OF UNIVERSITY OF PUERTO RICO

TABLE 2.-Yield data for corn top crosses test at Isabela Substation ${ }^{1}$

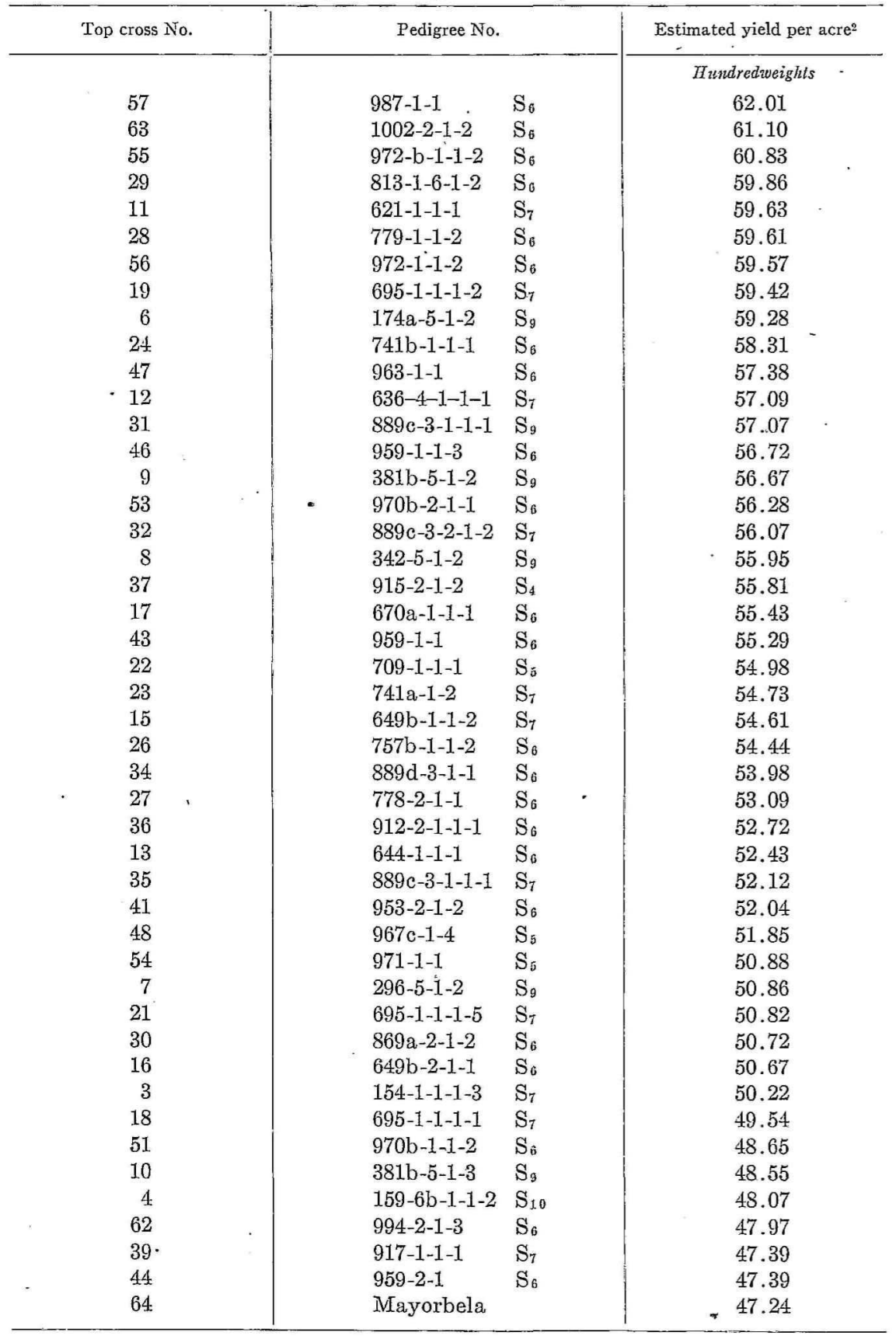


TABLE 2,-Continued

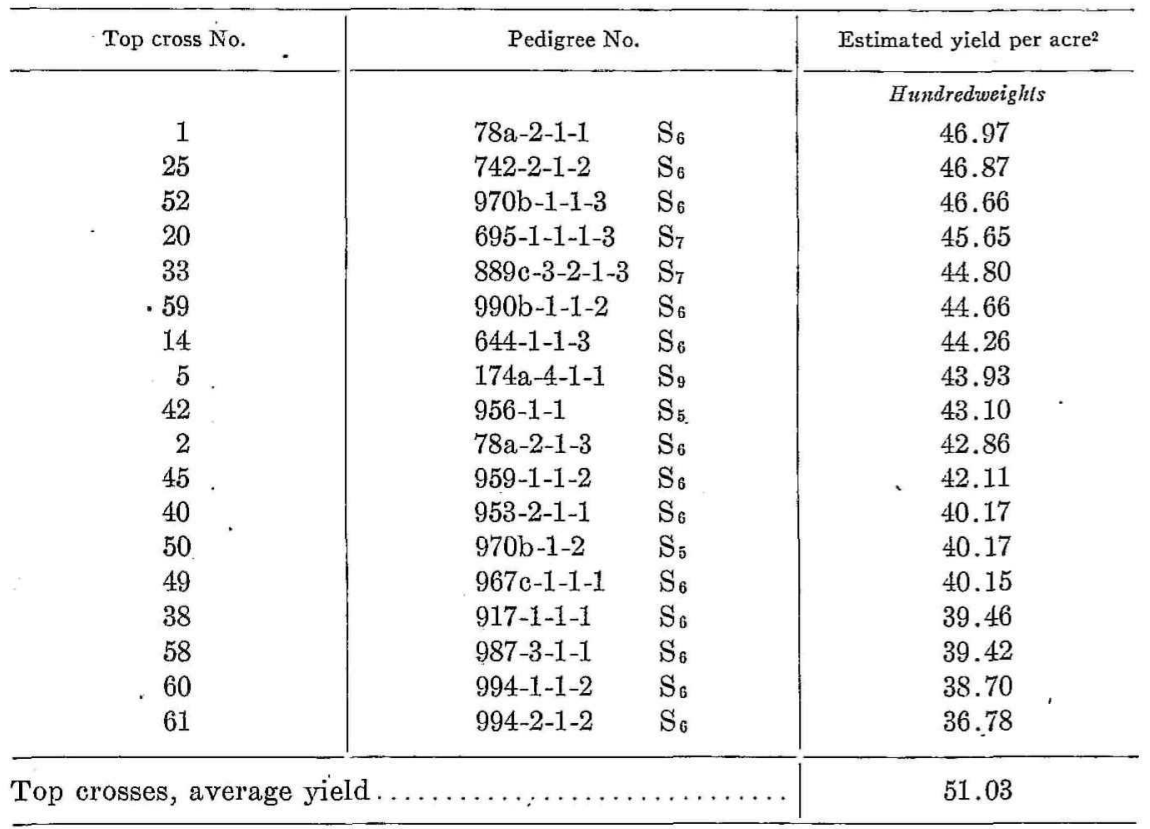

${ }^{1}$ Planted MLarch 16, 1950; harvested June 29, 1950. Size of plots: 1/580.8 acre.

${ }^{2}$ Least significant difference at the 5 -per cent point-3.89 $\mathrm{cwt}$.; at the 1 -per cent point-4.76 cwt.

planted, 1 row of Mayorbela for each 2 rows of inbreds, the Mayorbela being used as the pollen parent. The inbreds (seed parents) were detasseled as soon as the tassels were emerging and before pollen-shedding began.

Because there were insufficient top-crossed seed of every line, 63 top crosses were tested at the Isabela Substation with Mayorbela as a check, in the summer of 1950 , using a triple lattice design.

Another yield test, a triple lattice, including 80 top crosses, and Mayorbela as a check, was conducted at the Lajas Substation during the late summer and winter of 1950 .

Analyses of variance were made for each yield trial and least-significant differences at the 1- and the 5-percent points for yield per acre, were used as a basis for determining the combining ability of this group of lines.

\section{EXPERIMENTAL ResULTS}

The yield tests for determining the combining ability of a group of native inbred lines were carried out as described above.

In the yield test at Isabela, 31 top crosses out of 63 , or almost 50 percent, outyielded-Mayorbela significantly at the 1-percent point, as shown in 
TABLE 3.-Yield data for corn top crosses test at Lajas Substation ${ }^{1}$

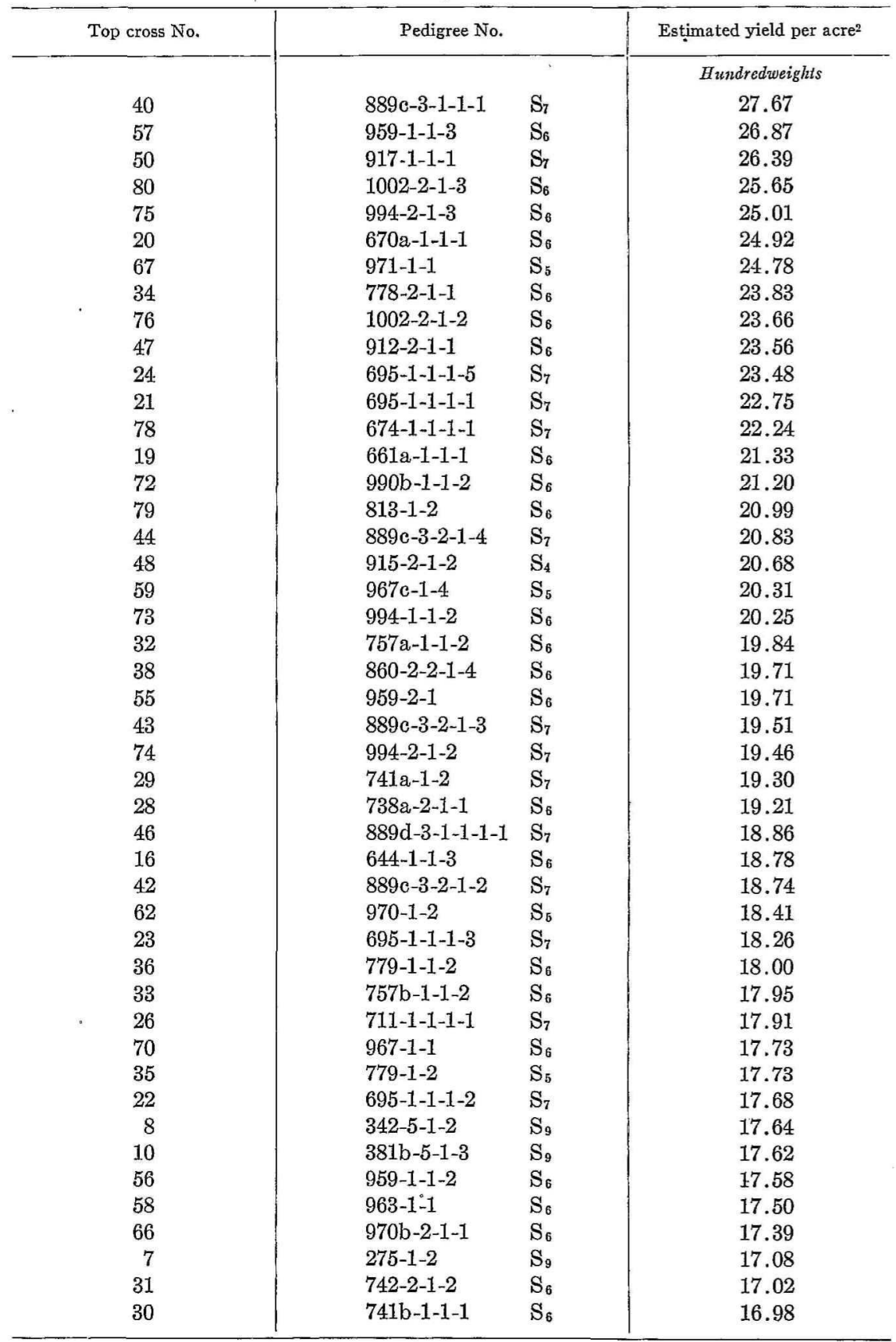


TABLE 8.-Continued

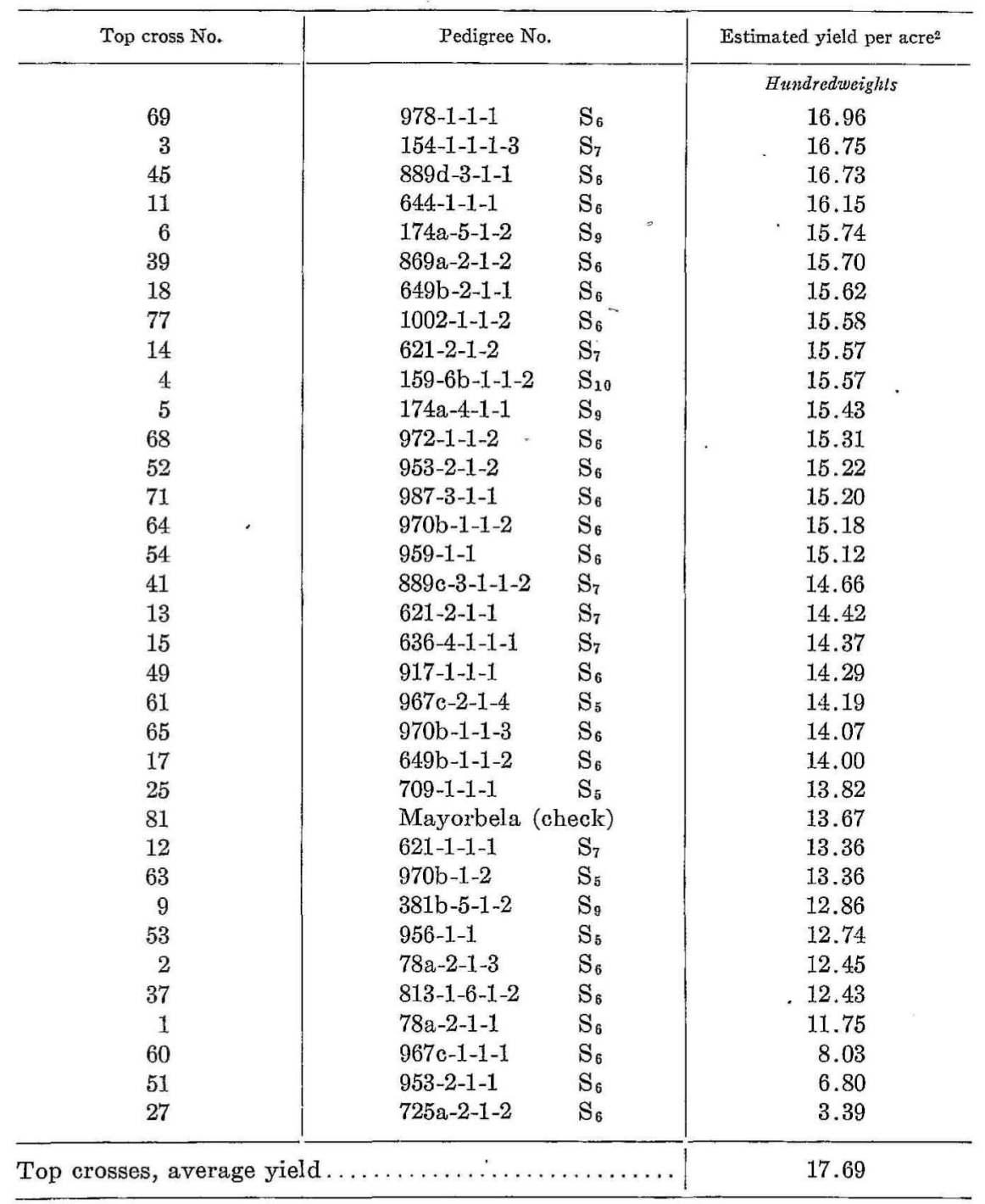

1 Planted August 28, 1950; harvested January 1951. Size of plots: 1/580.8 acre.

${ }^{2}$ Least significant difference at the 1-per cent point-2.69 cwt.; at the 5-per cent point-2.21 cwt.

table 2. The average yield of the top crosses, 51.03 cwt. per acre, was almost equal to the limit of significance from the check at the 5 -percent point, 51.3 cwt. per acre. 
TABLE 4.-Comparison of individual yields of top crosses with Mayorbela (check)

[Data from Isabela and Lajas tests]

\begin{tabular}{|c|c|c|c|c|c|c|c|}
\hline \multirow{2}{*}{$\begin{array}{c}\text { Top cross } \\
\text { No. }\end{array}$} & \multirow{2}{*}{\multicolumn{2}{|c|}{ Pedigree No. }} & \multicolumn{2}{|c|}{$\begin{array}{l}\text { Isabela data: } \\
\text { Increase or decrease } \\
(-) \text { in yield as } \\
\text { compared with check }\end{array}$} & \multirow{2}{*}{$\begin{array}{l}\text { Rank, } \\
\text { according to } \\
\text { yield at Lajas }\end{array}$} & \multicolumn{2}{|c|}{$\begin{array}{l}\text { Lajas data: } \\
\text { Increase or decrease } \\
(-) \text { in yield as } \\
\text { compared with check }\end{array}$} \\
\hline & & & $\begin{array}{c}\text { Hundred- } \\
\text { weights } \\
\text { per acre }\end{array}$ & Percent & & $\begin{array}{c}\text { Hundred- } \\
\text { weights } \\
\text { per acre }\end{array}$ & Percent \\
\hline 57 & $987-1-1$ & $\mathrm{~S}_{6}$ & 14.77 & 31.27 & 36 & 4.06 & 29.0 \\
\hline 63 & $1002-2-1-2$ & $\mathbf{S}_{6}$ & 13.86 & 29.34 & 9 & 9.99 & 73.0 \\
\hline 55 & $972-1-1-2$ & $\mathrm{~S}_{6}$ & 13.59 & 28.77 & 58 & 1.64 & .10 .00 \\
\hline 29 & $813-1-6-1-2$ & $\mathrm{~S}_{6}$ & 12.62 & 26.71 & 77 & -1.24 & -9.0 \\
\hline 11 & $621-1-1-1-1$ & $S_{7}$ & 12.39 & 26.23 & 72 & -.31 & -2.0 \\
\hline 28 & $779-1-1-2$ & $S_{6}$ & 12.37 & 26.19 & 33 & 4.33 & 32.0 \\
\hline 56 & $972-1-1-2$ & $\mathrm{~S}_{9}$ & 12.33 & 26.10 & 58 & 1.64 & 10.0 \\
\hline 19 & $695-1-1-1-2$ & $S_{7}$ & 12.18 & 25.78 & 38 & 4.01 & 29.0 \\
\hline 6 & $174 a-5-1-2$ & $\mathrm{~S}_{9}$ & 12.04 & 25.49 & 51 & 2.07 & 15.0 \\
\hline 24 & $741 \mathrm{~b}-1-1-1$ & $\mathrm{~S}_{6}$ & 11.07 & 23.43 & 46 & 3.31 & 20.0 \\
\hline 47 & $963-1-1$ & $S_{6}$ & 10.14 & 21.46 & 42 & 3.83 & 28.0 \\
\hline 12 & $636-4-1-1-1$ & $S_{7}$ & 9.85 & 20.85 & 65 & .70 & 5.0 \\
\hline 31 & $889 c-3-1-1-1$ & $\mathrm{~S}_{9}$ & 9.83 & 20.81 & & & \\
\hline 46 & $959-1-1-3$ & $\mathrm{~S}_{6}$ & 9.48 & 20.07 & 2 & 13.20 & 97.0 \\
\hline 9 & $381 b-5-1-2$ & $S_{9}$ & 9.43 & 19.96 & 74 & -.81 & -5.9 \\
\hline 53 & $970 \mathrm{~b}-2-1-1$ & $\mathrm{~S}_{6}$ & 9.04 & 19.14 & 43 & 3.72 & 27.0 \\
\hline 32 & $889 c-3-2-1-2$ & $S_{7}$ & 8.83 & 18.69 & 30 & 5.07 & 37.0 \\
\hline 8 & $342-5-1-2$ & $\mathrm{~S}_{9}$ & 8.71 & 18.44 & 39 & 3.97 & 29.0 \\
\hline 37 & $915-2-1-2$ & $\mathrm{~S}_{4}$ & 8.57 & 18.14 & 18 & 7.01 & 51.0 \\
\hline 17 & $670 \mathrm{a}-1-1-1$ & $S_{6}$ & 8.19 & 17.34 & 6 & 11.25 & 82.0 \\
\hline 43 & $959-1-1$ & $S_{6}$ & 8.05 & 17.04 & 62 & 1.45 & 10.0 \\
\hline 22 & $709-1-1-1$ & $S_{\tilde{b}}$ & 7.74 & 16.38 & 70 & .15 & 1.0 \\
\hline 23 & $741 a-1-2$ & $\mathrm{~S}_{7}$ & 7.49 & 15.86 & 26 & 5.63 & 41.0 \\
\hline 15 & $649 b-1-1-2$ & $\mathrm{~S}_{7}$ & 7.37 & 15.60 & 69 & .33 & 2.0 \\
\hline 26 & $757 \mathrm{~b}-1-1-2$ & $S_{6}$ & 6.83 & 14.46 & 34 & 4.28 & 30.0 \\
\hline 34 & $889 \mathrm{~d}-3-1-1$ & $S_{6}$ & 6.74 & 14.27 & 49 & 3.06 & 20.0 \\
\hline 27 & $778-2-1-1$ & $S_{6}$ & 5.85 & 12.38 & 8 & 10.16 & 74.0 \\
\hline 36 & $912-2-1-1$ & $S_{0}$ & 5.48 & 11.60 & 10 & 9.89 & 72.0 \\
\hline 13 & $644-1-1-1$ & $S_{6}$ & 5.19 & 10.99 & 50 & 2.48 & 18.0 \\
\hline 35 & $889 c-3-1-1-1$ & $S_{7}$ & 4.88 & 10.33 & 1 & 14.00 & 100.0 \\
\hline 41 & $953-2-1-2$ & $S_{6}$ & 4.80 & 10.16 & 59 & 1.55 & 10.0 \\
\hline 48 & $967 \mathrm{e}-1-4$ & $\mathrm{~S}_{5}$ & 4.61 & 9.76 & 19 & 6.64 & 49.0 \\
\hline 54 & $971-1-1-1$ & $S_{5}$ & 3.64 & 7.71 & 7 & 11.11 & 81.0 \\
\hline 7 & $296-5-1-2$ & $\mathrm{~S}_{9}$ & 3.62 & 7.66 & & & \\
\hline 21 & $695-1-1-1-5$ & $S_{7}$ & 3.58 & 7.58 & 11 & 9.81 & 72.0 \\
\hline 30 & $869 a-2-1-2$ & $S_{6}$ & 3.48 & 7.37 & 52 & 2.03 & 15.0 \\
\hline 16 & $649 \mathrm{~b}-2-1-1$ & $\mathrm{~S}_{6}$ & 3.43 & 7.26 & 53 & 1.95 & 14.0 \\
\hline 3 & $154-1-1-1-3$ & $\mathrm{~S}_{7}$ & 2.98 & 6.31 & 48 & 3.08 & 20.0 \\
\hline 18 & $695-1-1-1-1$ & $\mathrm{~S}_{7}$ & 2.30 & 4.87 & 12 & 9.08 & 66.0 \\
\hline 51 & $970 b-1-1-2$ & $S_{6}$ & 1.41. & 2.98 & 61 & 1.51 & 10.0 \\
\hline 10 & $381 b-5-1-3$ & $\mathrm{~S}_{9}$ & .31 & 2.77 & 40 & 3.95 & 28.0 \\
\hline
\end{tabular}


TABLE 4.-Continued

\begin{tabular}{|c|c|c|c|c|c|c|c|}
\hline \multirow{2}{*}{$\begin{array}{c}\text { Top cross } \\
\text { No. }\end{array}$} & \multirow{2}{*}{\multicolumn{2}{|c|}{ Pedigree No. }} & \multicolumn{2}{|c|}{$\begin{array}{c}\text { Isabela data: } \\
\text { Increase or decrease } \\
(-) \text { in yield as } \\
\text { compared with check }\end{array}$} & \multirow{2}{*}{$\begin{array}{c}\text { Rank, } \\
\text { according to } \\
\text { yield at Lajas }\end{array}$} & \multicolumn{2}{|c|}{$\begin{array}{l}\text { Lajas data: } \\
\text { Increase or decrease } \\
(-) \text { in yield as } \\
\text { compared with cileck }\end{array}$} \\
\hline & & & $\begin{array}{l}\text { Hundred- } \\
\text { weights } \\
\text { per acre }\end{array}$ & Percent & & $\begin{array}{c}\text { Hundred- } \\
\text { weights } \\
\text { per acre }\end{array}$ & Percent \\
\hline 4 & $159-6 b-1-1-2$ & $S_{10}$ & .83 & 1.76 & 56 & 1.90 & 14.0 \\
\hline 62 & $994-2-1-3$ & $\mathrm{~S}_{6}$ & .73 & 1.55 & 5 & 11.34 & 83.0 \\
\hline 39 & $917-1-1-1$ & $\mathrm{~S}_{7}$ & .15 & .32 & 3 & 12.72 & 93.0 \\
\hline 44 & $959-2-1$ & $\mathrm{~S}_{6}$ & .15 & .32 & 23 & 6.04 & 43.0 \\
\hline 64 & Mayorbela & & & & 71 & & \\
\hline 1 & $78 a-2-1-1$ & $\mathbf{S}_{6}$ & -.27 & -.57 & 78 & -1.92 & -14.0 \\
\hline 25 & $742-2-1-2$ & $S_{6}$ & -.37 & -.78 & 45 & 3.35 & 20.0 \\
\hline 52 & $970 \mathrm{~b}-1-1-3$ & $\mathrm{~S}_{6}$ & -.58 & -1.23 & 68 & .40 & 2.9 \\
\hline 20 & $695-1-1-1-3$ & $S_{7}$ & -1.59 & -3.37 & 32 & 4.59 & 34.0 \\
\hline 33 & $889 c-3-2-1-3$ & $\mathrm{~S}_{7}$ & -2.44 & -5.17 & 24 & 5.84 & 43.0 \\
\hline 59 & $990 \mathrm{~b}-1-1-2$ & $\mathrm{~S}_{6}$ & -2.58 & -5.46 & 15 & 7.53 & 55.0 \\
\hline 14 & $644-1-1-3$ & $\mathbf{S}_{6}$ & -2.98 & -6.31 & 29 & 5.11 & 37.0 \\
\hline 5 & $174 a-4-1-1$ & $\mathrm{~S}_{9}$ & -3.31 & -7.01 & 57 & 1.76 & 14.0 \\
\hline 42 & $956-1-1$ & $S_{5}$ & -4.14 & -8.76 & 75 & -.93 & -6.8 \\
\hline 2 & $78 a-2-1$ & $\mathrm{~S}_{0}$ & -4.38 & -9.27 & 78 & -1.92 & $-14.0^{\circ}$ \\
\hline 45 & $959-1-1-2$ & $S_{0}$ & -5.13 & -10.86 & 41 & 3.91 & 28.0 \\
\hline 40 & $953-2-1-1$ & $\mathrm{~S}_{6}$ & -7.07 & -14.97 & 80 & -6.87 & -50.0 \\
\hline 50 & $970 b-1-2$ & $\mathrm{~S}_{5}$ & -7.07 & -14.97 & 73 & -.31 & -2.0 \\
\hline 49 & $967 c-1-1-1$ & $\mathrm{~S}_{6}$ & -7.09 & -15.01 & 79 & -5.64 & -41.0 \\
\hline 38 & $917-1-1-1$ & $\mathrm{~S}_{\tilde{s}}$ & -7.78 & -16.47 & 66 & .62 & 4.5 \\
\hline 58 & $987-3-1-1$ & $\mathrm{~S}_{6}$ & -7.82 & -16.55 & 60 & 1.53 & 11.19 \\
\hline 60 & $994-1-1-2$ & $\mathrm{~S}_{6}$ & -8.54 & -18.08 & 20 & 6.58 & 48.0 \\
\hline 61 & $994-2-1-2$ & $S_{6}$ & -10.46 & -22.14 & 25 & 5.79 & 42.0 \\
\hline \multicolumn{3}{|c|}{ Top crosses, average.......... } & 3.79 & 8.02 & & 4.02 & 29.41 \\
\hline
\end{tabular}

${ }^{1}$ Minus sign indicates yield below check. Blank spaces indicate missing data.

At Lajas, 49 top crosses out of 80, or 61 percent, outyielded Mayorbela significantly at the 1-percent point. The average yield of the top crosses, 17.69 ervt. per acre, was significant over that of the check at the 1-percent point. (See table 2.)

At Isabela, 24 top crosses gave increases in yield over Mayorbela of over 15 per cent and up to 31 percent, equivalent to a range of 7 to 14 cwt. per acre, as shown in table 3.

In the Lajas test, 52 top crosses produced increases in yield over Mayorbela of from 15 to 100-percent, which is equivalent to a range of 2 to 14 cwt. per acre. (See table 3.)

The data indicated definite variations in the performance of some top crosses at Isabela, as compared with those at Lajas, as shown in table 4. 
The best top crosses did not perform the same at both experimental sites, obviously because Isabela has irrigation facilities, while Lajas is a very dry region with no irrigation. Also, weather and soil conditions are quite different in these two regions.

\section{Discusston}

It is known that most varieties or hybrids adapt themselves differently under diverse environmental conditions. These differences in performance of the top crosses, as shown above, might be explained as being the consequence of genetic variability as modified by the environmental requirements of the lines tested.

The ultimate objective of producing inbred lines is to utilize them for the production of hybrids, so their final selection is based on their performance as hybrids.

The inbred-variety cross (top cross) is used to measure the average general combining ability of the inbred. However, this test is principally used for the preliminary screening out of lines of low or inferior combining ability. It must be supplemented by the single-cross performance test, to measure the specific combining ability of the line. The single crosses are being tested and the results should provide the necessary information to determine how the lines will nick.

The results so far obtained indicate that a number of pure lines with a high combining value are now available and this is fundamental to the production of high-yielding hybrids.

On the basis of this information there is no doubt that the possibilities for corn production in the Island can be improved with the development of high-yielding hybrids.

Although the yield results presented here are based on two tests only, they nevertheless indicate that some of the inbred lines developed possess a high combining value for the production of hybrids superior to our present varieties. Discounting the economic considerations which determine the feasibility of producing hybrid corn in Puerto Rico, it is expected that some of these lines will give rise to hybrids that, in turn, will increase local corn production considerably. With the development of additional new lines, and through the improvement of the original inbred stocks, new hybrids of superior yielding capacity can be produced to replace the original hybrids and thus increase Puerto Rican corn yields.

It is expected that the use of hybrid seed in Puerto Rico will cause farmers some difficulties. As it is, they have been producing their own seed corn every year for many generations. But the farmer must obtain hybrid seed corn from the producer each season. It is believed that this practice will not be readily accepted by corn growers. The value of this deviation from 
daily routine will have to be demonstrated and proved before it is accepted. Therefore, an intensive educational campaign is necessary to teach farmers the approved practices to be followed in the production and utilization of hybrid corn seed.

\section{SUMMARY}

A breeding program for the improvement of corn production in Puerto Rico is being carried on. A number of inbred lines have been developed and tested in top crosses. Results obtained in these tests show that some of these lines possess a high combining value, which is the primary basis for the production of high-yielding hybrids.

The data so far obtained indicate that the possibilities for improving corn production in Puerto Rico by developing high-yielding hybrids are promising.

\section{Literature Cited}

1. Annual Book of Statistics of Puerto Rico, 1949-50.

2-13. Reports of the Puerto Rico Agricultural Experiment Station, (2) 1921, pp. 14, 18 ; (3) 1922 , p. 9 ; (4) 1923 , pp. $7-8$; (5) 1924 , pp. $21-23$; (6) 1925, pp. 15-16;

(7) 1926, pp. 22-24; (8) 1927, pp. 14-15; (9) 1928, pp. 20-22; (10) 1929, pp. 21-22;

(11) 1930, pp. 17-19; (12) 1931, pp. 19-22; (13) 1932, p..16.

14-20. Annual Reports of the Agricultural Experiment Station of the University of Puerto Rico, (14) 1936-37, pp. 119-120; (15) 1937-38, p. 47; (16) 1938-39, p. 61; (17) $1939-40$, p. 43 ; (18) 1940-41, p. 58; (19) 1941-42, p. 30; (20) 1942-43, p. 37; (21) $1943-44$, p. 44.

22. Annual Report of the Agronomy and Horticulture Department, Agricultural Experiment Station of the University of P. R. 1944-45, pp. 5-6 (unpublished).

23. Annual Report of the Plant Breeding Department, Agricultural Experiment Station of the University of Puerto Rico, 1945-46, pp. 2-3 (unpublished).

24. Harland, S. C. 1946. A New Method of Maize Improvement, Tropical Agriculture, 23 (6), p. 114. 